\title{
New Fluorescent, Thermally Stable and Film Forming Polyimines Containing Naphthyl Rings
}

\author{
Farah Qureshi, ${ }^{\star}$ Muhammad Yar Khuhawar and Taj Muhammad Jahangir \\ Institute of Advanced Research Studies in Chemical Sciences, University of Sindh, Jamshoro, Sindh-Pakistan \\ * Corresponding author: E-mail: farahqureshi94@yahoo.com \\ Tel: $+92-229213213,+92-3313534844$
}

Received: 03-01-2019

\begin{abstract}
Three new aliphatic-aromatic polymers having naphthyl rings were prepared by the polycondenstion of dialdehydes or diketone monomers with 1,5-naphthalenediamine or 1,4-phenylenediamine. The monomers were prepared by the reaction of aromatic aldehyde or ketone with 1,6-dibromohexane. The molecular mass of the monomers was confirmed through E.I mass spectroscopy. The structures of monomers and polymers were characterized by ${ }^{1}$ HNMR, FT-IR, UV-Vis Spectroscopy, SEM and TG/DTA. Fluorescence emissions of monomers and polymers were recorded and their quantum yields were calculated, all the compounds showed fluorescence property and indicated violet, blue-green, orange and red light emissions. The quantum yields of the polymers were obtained within the range of 0.04 to $24.3 \%$. The semicrystalline and amorphous nature of the polymers was analyzed through powdered X-ray diffraction. Antimicrobial activities of the polymers were examined against different bacterial and fungal species. Thin film forming ability of the synthesized polymers was evaluated by making their blends with PVC (poly vinyl chloride) in different $\mathrm{w} / \mathrm{w} \%$ ratios.
\end{abstract}

Keywords: Polyimines; fluorescence; thermal stability; thin films; morphology

\section{Introduction}

Schiff base polymers also called polyimines or polyazomethines $(\mathrm{CH}=\mathrm{N})$ have been the subject of interest from last several decades and prepared by the polycondensation reaction of carbonyl compounds (dialdehydes or diketones) with aliphatic or aromatic diamines. ${ }^{1-3}$ The researchers are attracted towards the synthesis of new polyimines because of their advantageous properties such as liquid-crystalline, ${ }^{4}$ fluorescence, ${ }^{5,6}$ optical and electronic properties, ${ }^{7,8}$ high thermal stability, ${ }^{9,10}$ fiber forming, ${ }^{11,12}$ thin film forming, ${ }^{13-15}$ coordination abilities with metal ions $^{16}$ and antimicrobial activities. ${ }^{17,18}$ These properties make them important candidate for application in solar cells, ${ }^{19,20}$ optoelectronic sensors, ${ }^{21}$ photo-luminescent devices, ${ }^{22}$ aerospace, ${ }^{23}$ packaging materials and antifouling paints. ${ }^{24}$ The redox activity of the Schiff base polymers was also reported, therefore they can be employed as redox indicators. ${ }^{25}$ The polymer blends are also seeking attention in technological fields during last two decades because of their mechanical properties, which can be altered according to desired application. ${ }^{26}$ The polymer blends comprise about $30 \%$ of the total industrial plastic products. ${ }^{27}$ However aromatic polyimines are difficult to process due to their low solubility and high melting points which limits their applications. ${ }^{28}$ To overcome these difficulties researchers have made different attempts which are introduction of ester, ether, alkyl or alkoxy groups and chains of methylene spacers between the aromatic rings. ${ }^{29,30}$ Mondal and Das reported the effect of chain flexibility on the morphology of polyamides, they have observed decrease in thermal stability with the inclusion of aliphatic chains. ${ }^{31}$ In the present work three new polyimines were prepared by the polycondensation reaction of dialdehydes or diketone monomers with diamines. The obtained polymers contained flexible aliphatic spacers of $n$-hexane and ether linkages between the aromatic rings. One of the polymers (PoHOAND) contained alkyl group attached with the imine bond. These structural variations have effected on the solubility and other properties (thermal stability, fluorescence and thin film forming ability) of polyimines.

\section{Experimental}

\section{1. Materials}

3-hydroxybenzaldehyde (Sigma-Aldrich Corp. St. Louis, MO USA) (purity 99\%), 2-hydroxyacetophenone 
(Fluka, Switzerland), 2-hydroxynaphthaldehyde (Sigma-Aldrich Corp. St. Louis, MO USA), 1,6-dibromohexane (Sigma Aldrich, St. Louis USA) (purity 96\%), 1,4-phenylenediamine (Alfa-Aesar, UK) (purity 97\%), 1,5-naphthalenediamine (Toshima, Kita-ka, Tokyo, Japan), N,N-dimethylformamide (AnalaR BDH, England) (purity 98\%), dimethylsulfoxide (AnalaR BDH, England), anhydrous sodium carbonate (Sigma-Aldrich, Germany), p-toluenesulfonic acid monohydrate (Daejung Chemicals \& Metals Co. Ltd. Korea) (purity 99\%), ethanol (E. Merck, Germany), potassium hydroxide (E. Merck, Gerrmany), chloroform (Merck, KGaA, Darmstadt, Germany), tetrahydrofuran (THF) (E. Merck, Germany), acetone (Sigma-Aldrich Chemie GmbH, Steinheim, Germany) (purity 99.5\%), quinine sulfate (Alfa-Aesar, UK) (98\% purity) and poly vinyl chloride (Sigma-Aldrich Corp. St. Louis, MO USA) were used without further purification and double distilled water obtained from glass assemblies.

\section{2. Characterization}

The melting point of the monomers and polymers were recorded on Gallenkamp Melting point apparatus (made in England) equipped with thermometer. The E.I mass spectra of the monomers were recorded on JEOL JMS-600 (Japan) mass spectrometer at HEJ Research Institute of Chemistry, University of Karachi, Sindh-Pakistan. The Proton NMR ( ${ }^{1} \mathrm{HNMR}$ ) spectra of the monomers and polymers were recorded on BRUKER AVANCE-NMR 400 MHz spectrometer at HEJ Research Institute of Chemistry, University of Karachi, Sindh-Pakistan, using TMS as internal standard and deuterated dimethylsulfoxide (DMSO- $d_{6}$ ) as solvent. The FT-IR spectra of the monomers and polymers were recorded on Thermo Scientific ${ }^{\mathrm{Tm}}$ Nicolet iS10 FT-IR Spectrometer with Attenuated total reflectance (ATR) accessory equipped with OMNIC ${ }^{\mathrm{m}}$ Software. The UV-Visible spectra of monomers and polymers were recorded within $200-700 \mathrm{~nm}$ spectral range on a double beam spectrophotometer Shimadzu UV-1800 with UV Probe software at Mehran University of Engineering \& Technology, Jamshoro, Sindh-Pakistan, using $1 \mathrm{~cm}$ quartz cuvettes and DMSO as solvent. The Fluorescence emission spectra of monomers and polymers were recorded on Spectrofluorophotometer RF-5301PC Series (Shimadzu, Kyoto, Japan) using $1 \mathrm{~cm}$ quartz cuvette and DMSO as solvent. The morphologies of the compounds were observed through SEM images recorded on Scanning Electron Microscope JEOL JSM-6490 LV at Center for Pure and Applied Geology, University of Sindh, Jamshoro, Sindh-Pakistan or on JEOL JSM 5910 at Centralized Resource Laboratory (CRL), University of Peshawar, Peshawar-Pakistan, using $15 \mathrm{kV}$ accelerating voltage. The powder X-ray diffraction (XRD) of the polymers was recorded on X-ray Diffractometer JDX 3532 (JEOL, Japan) equipped with $\mathrm{Cu}$ $\mathrm{Ka}$ radiation (wavelength: $1.54056 \AA$ ) at Centralized Resource Laboratory, University of Peshawar, Peshawar- Pa- kistan. The TG/DTA graphs of monomers and polymers were recorded at Centralized Resource Laboratory, University of Peshawar, Peshawar- Pakistan on Pyris Diamond Series TG/DTA (Perkin Elmer, USA) thermal analyzer in nitrogen atmosphere with flow rate of $20 \mathrm{ml} / \mathrm{min}$ and heating rate of $20^{\circ} \mathrm{C} / \mathrm{min}$, the sample $(5-10 \mathrm{mg}$ ) was placed on ceramic pan and heated from $50{ }^{\circ} \mathrm{C}$ to $800{ }^{\circ} \mathrm{C}$ using alumina as reference material. Thin film forming ability of the polymers were tested by making their blends with PVC (poly vinyl chloride) in different $\mathrm{w} / \mathrm{w}$ ratios $(10-50 \%)$. The polymers were dissolved separately in DMSO while PVC was dissolved in THF and their mixtures $(10-50 \%) \mathrm{w} / \mathrm{w}$ were transferred in glass Petri dishes of 2 inch diameter, the petri dishes were placed in an oven at $60{ }^{\circ} \mathrm{C}$ for evaporating the solvent. After drying the resulting thin films were removed from the glass surface of petri dishes with the help of spatula and the film forming ability of the polymers was confirmed as thin layers were easily separated from the glass surface without breaking. Antibacterial activities of the polymers were examined by microplate alamar blue assay using 96 well plate method. The antibacterial activities of the polymers were tested against different strains of bacteria which included Staphylococcus aureus, Salmonella typhi, Pseudomonas aeruginosa, Bacillus subtilis and Escherichia coli using Ofloxacin as standard drug. The polymer (2 to $4 \mathrm{mg}$ ) was dissolved in DMSO to make concentration 50 or $200 \mu \mathrm{g} / \mathrm{ml}$. The growth of bacteria was carried out in Mueller-Hinton Agar medium and the incubation period was 18 to $20 \mathrm{hrs}$. The \% inhibition of bacterial species by the polymers was calculated by using reported method and formula given as equation $1 .{ }^{32}$

$$
\% \text { inhibition }=\frac{\left(\varepsilon_{o x}\right) \lambda_{2} A \lambda_{1}-\left(\varepsilon_{o x}\right) \lambda_{1} A \lambda_{2}}{\left(\varepsilon_{\text {red }}\right) \lambda_{1} A^{\prime} \lambda_{2}-\left(\varepsilon_{\text {red }}\right) \lambda_{2} A^{\prime} \lambda_{1}} \times 100
$$

Where $\varepsilon_{\mathrm{ox}}$ and $\varepsilon_{\text {red }}$ are the molar extinction coefficient of Alamar blue dye in the oxidized (blue) and reduced (pink) form respectively, $\lambda_{1}=570 \mathrm{~nm}, \lambda_{2}=600 \mathrm{~nm}$, $A$ and $A^{\prime}$ are the absorbance reading of the test and negative control well respectively. The antifungal activities of the polymers were tested by agar tube dilution method against different fungal strains which were Candida albicans, Canadida glabrata, Aspergillus niger, Fusarium lini, Trichphyton rubrum and Microsporum canis using standard drug Amphotericin B for Aspergillus niger and Miconazole for other species. SDA (Sabouraud dextrose agar) media was used for fungal growth where $12 \mathrm{mg}$ of polymer was dissolved in DMSO to make concentration $200 \mu \mathrm{g} / \mathrm{ml}$. The incubation period was 7 days and the temperature was $27^{\circ} \mathrm{C}$. The $\%$ inhibition of fungal strains by the polymers was calculated using the formula given as equation 2 .

$$
\begin{aligned}
& \% \text { inhibition }= \\
& 100-\frac{\text { linear growth in test }(\mathrm{mm})}{\text { linear growth in control }(\mathrm{mm})} \times 100
\end{aligned}
$$




\section{3. Synthesis of Monomers}

Three new monomers (two dialdehydes and one diketone) were prepared by following a reported procedure. $^{33-35} 0.2 \mathrm{~mol}$ of aromatic aldehyde [3-hydydroxybenzaldehyde (24.42 g), 2-hydroxynaphthaldehyde (34.43 g) or 2-hydroxyacetophenone (27.23 g)] dissolved in $50 \mathrm{ml}$ of DMF was added into $250 \mathrm{ml}$ round bottom flask equipped with a condenser and magnetic stirrer, $0.25 \mathrm{~mol}$ ( $25 \mathrm{~g})$ anhydrous sodium carbonate and $0.1 \mathrm{~mol}$ of 1,6-dibromohexane $(15.38 \mathrm{ml})$ were also added to the reaction flask. The contents were refluxed for $5 \mathrm{~h}$ at $150{ }^{\circ} \mathrm{C}$ with continuous stirring, the resulting product was poured into $500 \mathrm{ml}$ cold water and allowed to form precipitates. The precipitates were filtered and washed once with $0.1 \mathrm{M}$ potassium hydroxide and then three times with distilled water, dried and recrystallized from ethanol. The structures and the reactions for the syntheses of monomers are given in Figure 1.

\section{3. 1. 3,3'-hexamethylenebis(oxybenzaldehyde) (m-HOB)}

Yield $=78 \%$, Mp. $60{ }^{\circ} \mathrm{C}, \mathrm{C}_{20} \mathrm{H}_{22} \mathrm{O}_{4}$, FT-IR cm ${ }^{-1}$ (relative intensity) 3066(w), 2944(w), 2912(w), 2866(w), 2808(w), 2719(w), 1717(m), 1694(s), 1592(m), 1486(m), 1472(m), 1450(m), 1384(m), 1323(m), 1294(w), 1258(s), 1169(s), 1148(m), 1082(w), 1021(s), 990(w), 931(w), 876(w), 864(w), 785(s), 755(s), 730(w), 682(s). ${ }^{1} \mathrm{HNMR}$ $\left(\mathrm{DMSO}-d_{6}\right), \delta \mathrm{ppm} \mathrm{1.489}(\mathrm{q}), 1.762(\mathrm{t}), 4.050(\mathrm{t}), 7.258(\mathrm{~m})$, 7.405(d), 7.486(m), 9.959. UV (DMSO), $\lambda$-max, nm ( $\varepsilon, \mathrm{L}$. $\mathrm{mole}^{-1} \mathrm{~cm}^{-1}$ ) 314(6976). E.I mass spectrum $\mathrm{m} / \mathrm{z}$ (relative intensity \%) $\mathrm{M}^{+}$326(33.2), 297(1.3), 221(1.5), 205(8.1), $177(5.0), \quad 163(2.5), \quad 149(3.0), \quad 135(10.9), \quad 121(31.6)$, 105(19.4), 83(65.5), 55(100).

\section{3. 2. 2,2'-hexamethylenebis(oxynaphthaldehyde) (o-HON)}

Yield $=85 \%$, Mp. $180{ }^{\circ} \mathrm{C}, \mathrm{C}_{28} \mathrm{H}_{26} \mathrm{O}_{4}$, FT-IR cm ${ }^{-1}$ (relative intensity) 2939(w), 2878(w), 1990(w), 1661(s), 1620(w), 1590(m), 1511(m), 1459(w), 1434(m), 1368(w), 1343(m), 1268(m), 1246(s), 1150(s), 1058(s), 1022(m), 942(w), 900(w), 866(w), 804(s), 758(s), 708(m), 645(s). ${ }^{1} \mathrm{HNMR}$ (DMSO- $d_{6}$ ), $\delta$ ppm 1.361, 1.455(d), 1.575, 1.871, 4.324(t), 7.446(t), 7.589(m), 7.925(d), 8.257(q), 9.083(d), 10.794. UV (DMSO), $\lambda$-max, $\mathrm{nm}\left(\varepsilon, \mathrm{L} . \mathrm{mole}^{-1} \mathrm{~cm}^{-1}\right)$ 320(3043), 340(2199). E.I mass spectrum $\mathrm{m} / \mathrm{z}$ (relative intensity \%) $\mathrm{M}^{+}$426(52.2), 398(89.9), 397(28.3), 271(3.5), 255(19.3), 241(1.0), 227(8.2), 213(4.4), 199(3.2), 185(21.8), 171(100), 155(7.7), 83(30.6), 55(57.2).

\section{3. 3. 2,2'-hexamethylenebis(oxyacetophenone) (o-HOA)}

Yield $=81 \%$, Mp. $80{ }^{\circ} \mathrm{C}, \mathrm{C}_{22} \mathrm{H}_{26} \mathrm{O}_{4}$, FT-IR cm ${ }^{-1}$ (relative intensity) 2951(w), 2870(w), 1661(s), 1593(s), 1575(w), 1485(m), 1469(w), 1449(m), 1411(w), 1395(w), 1361(m), 1293(s), 1232(s), 1162(m), 1129(m), 1043(m), 1014(m), 865(m), 828(w), 763(s). ${ }^{1} \mathrm{HNMR}\left(\mathrm{DMSO}-d_{6}\right), \delta \mathrm{ppm}$ 1.530(t), 1.815(t), 2.534(d), 4.099(t), 6.989(t), 7.136(d), 7.500(m), 7.557(m). UV, $\lambda$-max, nm $\left(\varepsilon, L . \mathrm{mole}^{-1} \mathrm{~cm}^{-1}\right)$ 306(7076), 444(233.7). E.I mass spectrum $\mathrm{m} / \mathrm{z}$ (relative intensity \%) $\mathrm{M}^{+} 354(2.3), 339(19.5), 235(13.5), 219(20)$, 191(3.0), 177(1.5), 163(1.7), 149(23.9), 135(2.9), 119(13.9), 83(69.4), 55(100), 43(37.3).

\section{4. Synthesis of Polymers}

Three new polymers were synthesized by following reported method ${ }^{33-35}$ with slight modification in the proce- (i)<smiles>O=Cc1cccc(O)c1</smiles>
3-hydroxybenzaldehyde<smiles>O=Cc1cccc(OCCCCCCOc2cccc(C=O)c2)c1</smiles>

(ii)

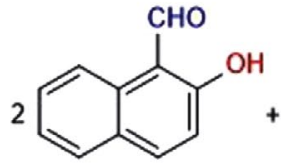
2-hydroxy-1-naphthaldehyde

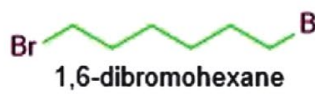

Br<smiles>O=Cc1c(OCCCCCCOc2ccc3ccccc3c2C=O)ccc2ccccc12</smiles>

2,2 '-hexamethylenebis(oxynaphthaldehyde) (O-HON)

(iii)<smiles>CC(=O)c1ccccc1O</smiles>
2'-hydroxyacetophenone<smiles>CC(=O)c1ccccc1OCCCCCCOc1ccccc1C(C)=O</smiles>

2,2'-hexamethylenebis(oxyacetophenone)(o-HOA)

Figure 1. Synthetic reactions for the dialdehydes or diketone monomers 


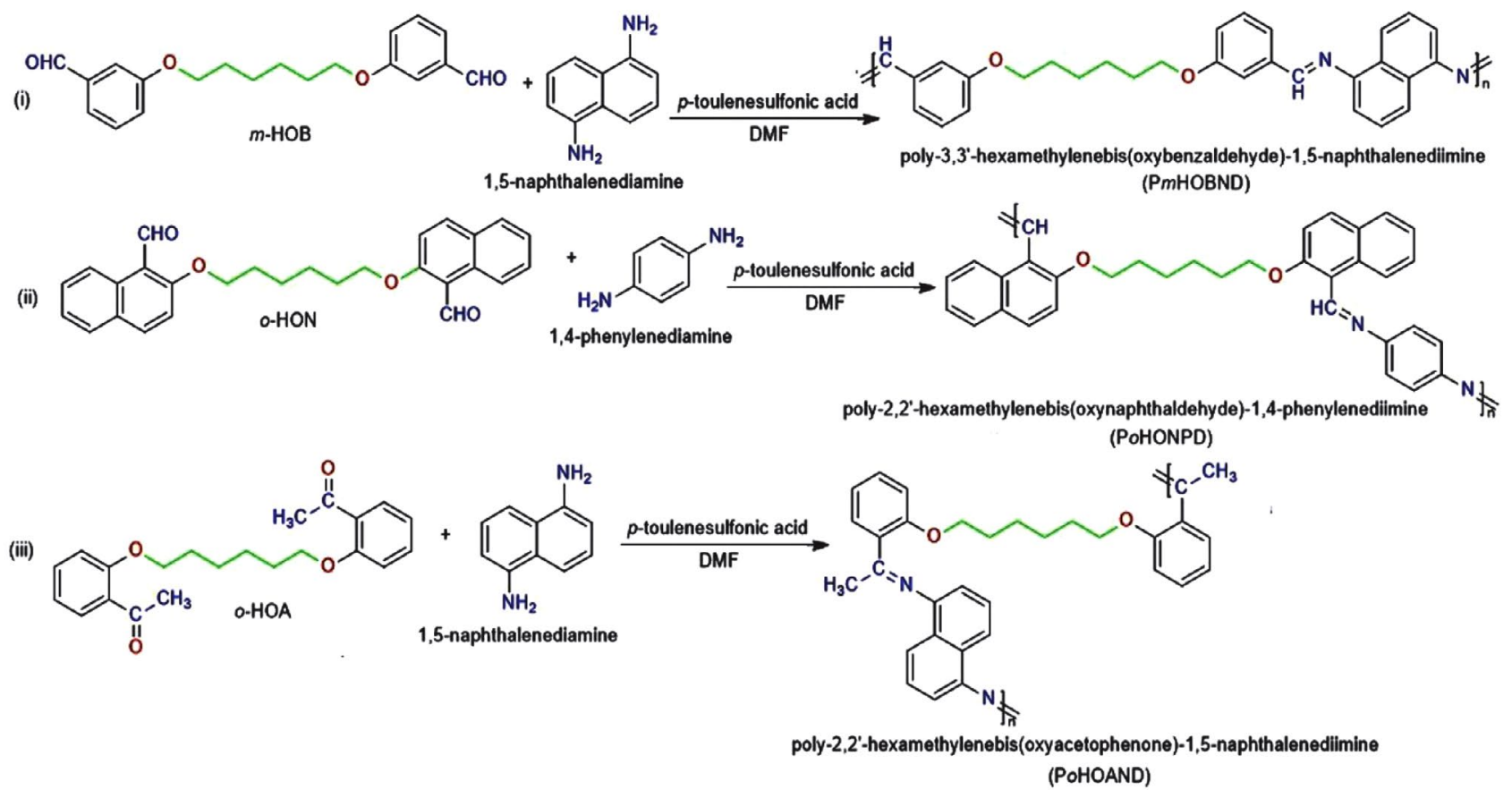

Figure 2: Synthetic reactions for the polyimines

dure as under: the monomer $(5 \mathrm{mmol})[\mathrm{m}$-HOB $(1.63 \mathrm{~g})$, $o$-HON $(2.13 \mathrm{~g})$ or $o$-HOA $(1.77 \mathrm{~g})]$ dissolved in $25 \mathrm{ml}$ DMF and $5 \mathrm{mmol}$ of diamine [1,5-naphthalenediamine $(0.79 \mathrm{~g})$ or 1,4-phenylenediamine $(0.54 \mathrm{~g})$ ] dissolved in 25 $\mathrm{ml}$ DMF were transferred in a $250 \mathrm{ml}$ round bottom flask equipped with condenser and magnetic stirrer bar and 0.01 $\mathrm{g}$ of $p$-toluenesulfonic acid was also added into the flask as catalyst. The contents were refluxed for 6 to 7 hours with continuous stirring in nitrogen atmosphere. The resulting product was poured into 250 or $500 \mathrm{ml}$ distilled water and allowed to settle precipitates. The product was filtered and finally dried at room temperature. The synthetic reactions for the polymers with their structures are given in Figure 2.

\section{4. 1. Poly-3,3'-hexamethylenebis(oxybenzldehyde)- 1,5-naphthalenediimine (PmHOBND)}

Yield $=76 \%$, Mp. $210^{\circ} \mathrm{C}$ (decomposed), $\left(\mathrm{C}_{30} \mathrm{H}_{28} \mathrm{~N}_{2} \mathrm{O}_{2}\right)_{\mathrm{n}}$, FT-IR, $\mathrm{cm}^{-1}$ (rel. intensity), 2939(w), 2863(w), 1694(w), 1620(m), 1578(s), 1503(w),1485(w), 1447(m), 1404(w), $1360(\mathrm{w}), 1360(\mathrm{w}), 1318(\mathrm{w}), 1248(\mathrm{~s}), 1206(\mathrm{~s}), 1174(\mathrm{w})$, 1150(m), 1024(m), 992(w), 974(w), 862(w), 778(s), 684(m). ${ }^{1} \mathrm{HNMR}$ (DMSO- $d_{6}$ ), $\delta$ ppm 1.496, 1.764, 2.721, 2.880, 4.052(m), 7.942, 9.980. UV (DMSO), $\lambda$-max nm (1\% absorptivity) 287(145), 321(236.5).

\section{4. 2. Poly-2,2'-hexamethylenebis(oxynaphthalde- hye)-1,4-phenylenediimine (PoHONPD)}

Yield $=78 \%$, Mp. $185-210{ }^{\circ} \mathrm{C},\left(\mathrm{C}_{34} \mathrm{H}_{30} \mathrm{~N}_{2} \mathrm{O}_{2}\right)_{\mathrm{n}}$, FT-IR, $\mathrm{cm}^{-1}$ (rel. intensity) 3367(w), 2936(w), 2857(w), 1683(w), 1618(w), 1592(s), 1505(w), 1487(w), 1456(m), 1387(w), 1285(m), 1243(s), 1188(w), 1143(s), 1101(s), 1073(w), 1005(w), 887(w), 826(m), 754(s), 722(m). ${ }^{1} \mathrm{HNMR}$ (DMSO- $d_{6}$ ), $\delta$ ppm 2.722, 2.881, 7.942. UV (DMSO), $\lambda$-max nm (1\% absorptivity) 265(1120), 318(940).

\section{4. 3. Poly-2,2'-hexamethylenebis(oxyacetophenone) -1,5-naphthalenediimine (PoHOAND)}

Yield $=74 \%$, Mp. $250^{\circ} \mathrm{C}$ (decomposed), $\left(\mathrm{C}_{32} \mathrm{H}_{32} \mathrm{~N}_{2} \mathrm{O}_{2}\right)_{\mathrm{n}}$, FT-IR, $\mathrm{cm}^{-1}$ (rel. intensity) 3339(w), 2938(w), 1594(s), 1517(w), 1485(w), 1450(s), 1407(w), 1358(w), 1293(m), 1237(m), 1164(w), 1122(w), 1033(w), 1010(w), 754(s), 681(m). ${ }^{1} \mathrm{HNMR}\left(\mathrm{DMSO}-d_{6}\right), \delta \mathrm{ppm} 1.223,1.417(\mathrm{~m}), 1.666$, 1.775(t), 2.275, 4.078(t), 6.594(t), 6.736(d), 6.986(t), 7.039, 7.114(m), 7.197(m), 7.308(t), 7.509(m). UV (DMSO), $\lambda$-max nm (1\% absorptivity) 307(1580), 477(500).

\section{Results and Discussion}

\section{1. Synthesis}

Three new monomers (dialdehydes or diketone) $m$-HOB, $o$-HON and $o$-HOA were prepared by condensation of 3-hydroxybenzaldehyde, 2-hydroxynaphthaldehyde or 2-hydroxyacetophenone with 1,6-dibromohexane. The monomers were obtained in good yield (78-85\%). In the present work new meta oriented dialdehyde $m$-HOB was prepared while its ortho and para oriented isomers were reported in our earlier work. ${ }^{34,35}$ Three new polyimines (P $m$ HOBND, PoHONPD and PoHOAND) were prepared by the polycondensation of dialdehydes or diketone monomers $(m-\mathrm{HOB}, o-\mathrm{HON}$ or $o$-HOA $)$ with di- 
amines (1,5-naphthalenediamine or 1,4-phenylenediamine). The polymers have ether linkages, azomethine or imine bonds and spacers of n-hexane between the aromatic rings and the polymer derived from diketone monomer (o-HOA) contains methyl group attached with the imine $(\mathrm{C}=\mathrm{N})$ group. The polymers were also obtained in good yield (74-78\%). The synthesized polymers can also be called as polyethers because all the three polymers contain ether linkages in their main chain.

\section{2. Solubility}

The solubility of the monomers and polymers was tested in various solvents and the results are given in Table 1. The monomers were soluble in organic solvents and in- soluble in water. The polymer PmHOBND was soluble in chloroform and THF without heating while in DMSO and DMF on heating, the polymer PoHONPD was soluble in DMF and DMSO on heating and the polymer PoHOAND indicated highest solubility in all the tested solvents except water, it is soluble in chloroform, acetone, THF, DMF and DMSO without heating while in ethanol with heating. The increased solubility of the polymer PoHOAND may be due to presence of methyl side group attached with the imine bond.

\section{3. E.I Mass Spectra of Monomers}

The mass spectrum of the dialdehyde $m$-HOB indicated $\mathrm{M}^{+}$at $\mathrm{m} / \mathrm{z} 326$ and other fragment ion peaks ap-

Table 1. Solubility of monomers and polymers in different solvents at the concentration of $5 \mathrm{mg} / 5 \mathrm{ml}$

\begin{tabular}{|c|c|c|c|c|c|c|c|c|}
\hline \multirow[t]{2}{*}{ S. No } & \multirow[t]{2}{*}{ Compound } & \multicolumn{7}{|c|}{ Solubility in different solvents } \\
\hline & & $\mathrm{H}_{2} \mathrm{O}$ & Ethanol & Acetone & Chloroform & THF & DMF & DMSO \\
\hline 1 & $m \mathrm{HOB}$ & IS & S & S & S & S & S & S \\
\hline 2 & $o \mathrm{HON}$ & IS & $\operatorname{PS}(\Delta)$ & $\mathrm{S}(\Delta)$ & S & S & S & S \\
\hline 3 & $o \mathrm{HOA}$ & IS & S & $\mathrm{S}$ & S & S & S & S \\
\hline 4 & PmHOBND & IS & IS & SS & S & S & $\mathrm{S}(\Delta)$ & $\mathrm{S}(\Delta)$ \\
\hline 5 & PoHONPD & IS & $\operatorname{SS}(\Delta)$ & $\operatorname{PS}(\Delta)$ & PS & PS & $\mathrm{S}(\Delta)$ & $\mathrm{S}(\Delta)$ \\
\hline 6 & PoHOAND & IS & $S(\Delta)$ & S & $\mathrm{S}$ & $S$ & $S$ & $S$ \\
\hline
\end{tabular}

S=Soluble, $\mathrm{S}(\Delta)=$ Soluble on heating, PS=Partially Soluble, PS $(\Delta)=$ Partially Soluble on heating, SS=Slightly Soluble, $S S(\Delta)=$ Slightly soluble on heating, IS=Insoluble

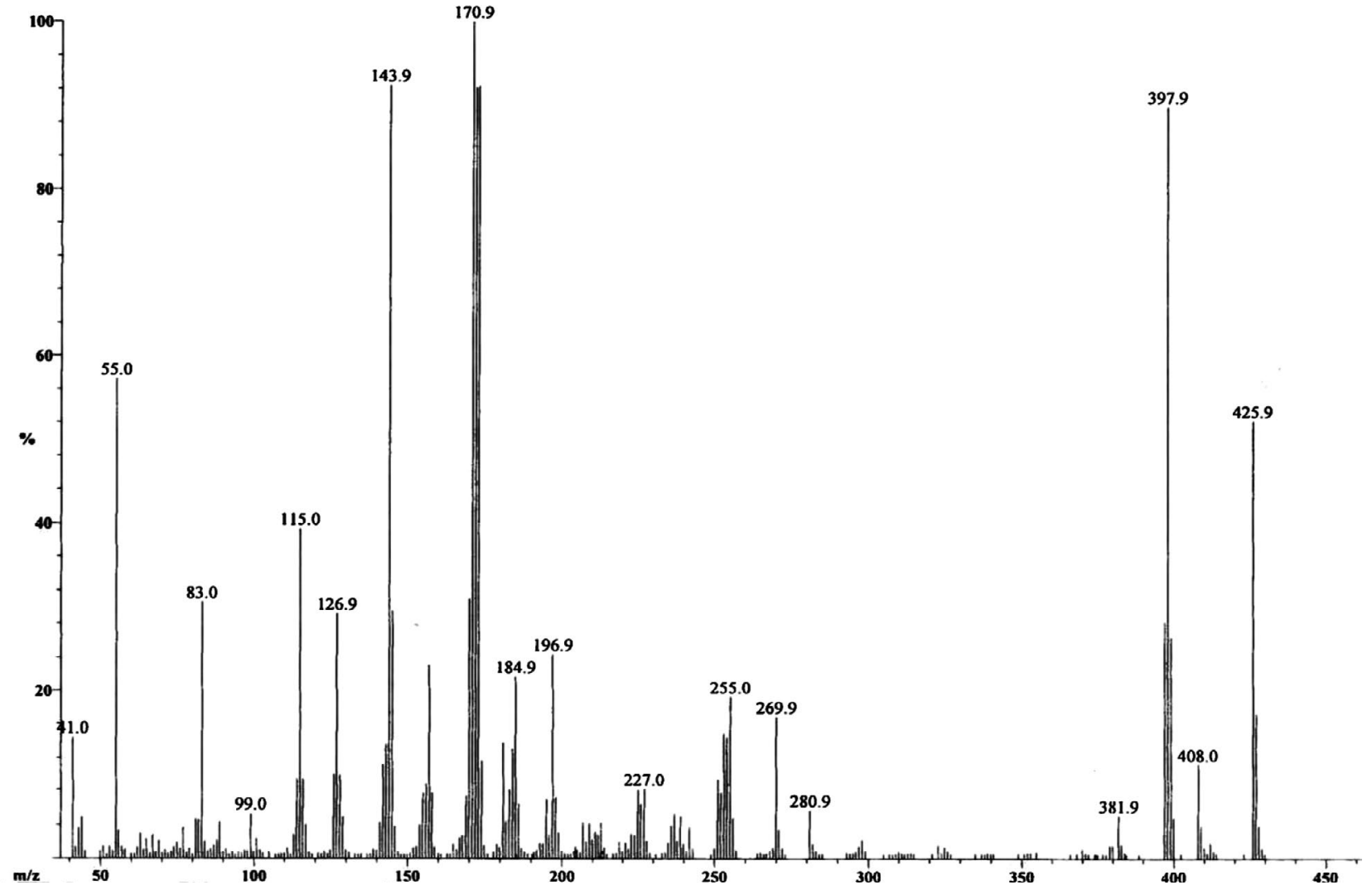

Figure 3. E.I mass spectrum of the monomer $o-\mathrm{HON}$ 
peared at $\mathrm{m} / \mathrm{z} 297,221,205,177,163,149,135,121$ and 105 corresponding to $[\mathrm{M}-(\mathrm{CHO})]^{+},\left[\mathrm{M}-\left(\mathrm{C}_{6} \mathrm{H}_{4} \cdot \mathrm{CHO}\right)\right]^{+}$, $\left[\mathrm{M}-\left(\mathrm{O} . \mathrm{C}_{6} \mathrm{H}_{4} \cdot \mathrm{CHO}\right)\right]^{+}, \quad\left[\mathrm{CHO} \cdot \mathrm{C}_{6} \mathrm{H}_{4} \cdot \mathrm{O} \cdot\left(\mathrm{CH}_{2}\right)_{4}\right]^{+}, \quad$ [CHO. $\left.\mathrm{C}_{6} \mathrm{H}_{4} \cdot \mathrm{O} .\left(\mathrm{CH}_{2}\right)_{3}\right]^{+}, \quad\left[\mathrm{CHO} . \mathrm{C}_{6} \mathrm{H}_{4} \cdot \mathrm{O} .\left(\mathrm{CH}_{2}\right)_{2}\right]^{+}, \quad[\mathrm{CHO}$. $\left.\mathrm{C}_{6} \mathrm{H}_{4} \cdot \mathrm{O}_{2} \mathrm{CH}_{2}\right]^{+}$, [CHO. $\left.\mathrm{C}_{6} \mathrm{H}_{4} . \mathrm{O}\right]^{+}$and $\left[\mathrm{CHO}^{-} \mathrm{C}_{6} \mathrm{H}_{4}\right]^{+}$respectively while the peaks at $83(65.5 \%)$ and $55(100 \%)$ corresponded to $\mathrm{C}_{6} \mathrm{H}_{11}$ and $\mathrm{C}_{4} \mathrm{H}_{7}$ (supplementary Fig. S1).

The mass spectrum of the dialdehyde $o$-HON indicated $\mathrm{M}^{+}$at $\mathrm{m} / \mathrm{z} 426$ and the other fragment ion peaks appeared at $\mathrm{m} / \mathrm{z} 398,397,271,255,241,227,213,199,185$, $171(100 \%)$ and 155 corresponding to $[\mathrm{M}-(\mathrm{CHO})+1]^{+}$, $[\mathrm{M}-(\mathrm{CHO})]^{+},\left[\mathrm{M}-\mathrm{C}_{10} \mathrm{H}_{6} \cdot \mathrm{CHO}\right]^{+},\left[\mathrm{CHO} \cdot \mathrm{C}_{10} \mathrm{H}_{6} \cdot \mathrm{O} .\left(\mathrm{CH}_{2}\right)_{6}\right]^{+}$, [CHO. $\left.\mathrm{C}_{10} \mathrm{H}_{6} \cdot \mathrm{O} .\left(\mathrm{CH}_{2}\right)_{5}\right]^{+}$, [CHO.C ${ }_{10} \mathrm{H}_{6}$. O. $\left.\left(\mathrm{CH}_{2}\right)_{4}\right]^{+}$, [CHO. $\left.\mathrm{C}_{10} \mathrm{H}_{6} \cdot \mathrm{O} .\left(\mathrm{CH}_{2}\right)_{3}\right]^{+}, \quad\left[\mathrm{CHO} \cdot \mathrm{C}_{10} \mathrm{H}_{6} \cdot \mathrm{O} .\left(\mathrm{CH}_{2}\right)_{2}\right]^{+}, \quad$ [CHO. $\left.\mathrm{C}_{10} \mathrm{H}_{6} \cdot \mathrm{O} \mathrm{CH}_{2}\right]^{+}$, [CHO. $\left.\mathrm{C}_{10} \mathrm{H}_{6} \cdot \mathrm{O}\right]^{+}$and $\left[\mathrm{CHO} \cdot \mathrm{C}_{10} \mathrm{H}_{6}\right]^{+}$respectively while the peaks at $83(30 \%)$ and $55(57.2 \%)$ were of $\mathrm{C}_{6} \mathrm{H}_{11}$ and $\mathrm{C}_{4} \mathrm{H}_{7}$ (Figure 3).

The mass spectrum of diketone $o$-HOA indicate $\mathrm{M}^{+}$ at $\mathrm{m} / \mathrm{z} 354$ and the other fragment ion peaks appeared at $\mathrm{m} / \mathrm{z} 339,235,219,191,177,163,149,135$ and 119 were corresponding to $\left[\mathrm{M}-\left(\mathrm{CH}_{3}\right)\right]^{+},\left[\mathrm{M}-\left(\mathrm{C}_{6} \mathrm{H}_{4} \cdot \mathrm{CO}^{-\mathrm{CH}_{3}}\right)\right]^{+}$, [M(O. $\left.\left.\mathrm{C}_{6} \mathrm{H}_{4} \cdot \mathrm{CO} \cdot \mathrm{CH}_{3}\right)\right]^{+}, \quad\left[\mathrm{CH}_{3} \cdot \mathrm{CO} \cdot \mathrm{C}_{6} \mathrm{H}_{4} \cdot \mathrm{O} \cdot\left(\mathrm{CH}_{2}\right)_{4}\right]^{+}, \quad\left[\mathrm{CH}_{3}\right.$. CO. $\left.\mathrm{C}_{6} \mathrm{H}_{4} \cdot \mathrm{O} \cdot\left(\mathrm{CH}_{2}\right)_{3}\right]^{+}, \quad\left[\mathrm{CH}_{3} \cdot \mathrm{CO} \cdot \mathrm{C}_{6} \mathrm{H}_{4} \cdot \mathrm{O} \cdot\left(\mathrm{CH}_{2}\right)_{2}\right]^{+}, \quad\left[\mathrm{CH}_{3}\right.$.


CO. $\left.{ }_{6} \mathrm{H}_{4}\right]^{+}$respectively while the peaks at 83(69.4), 55(100) and 43(37.3) were of $\mathrm{C}_{6} \mathrm{H}_{11}, \mathrm{C}_{4} \mathrm{H}_{7}$ and $\mathrm{CH}_{3} \mathrm{CO}$ respectively (supplementary Fig. S2).

\section{4. FT-IR Spectroscopy of Monomers and Polymers}

The FT-IR spectra of dialdehydes and diketone monomers indicated two or five weak bands within 2951$2719 \mathrm{~cm}^{-1}$ due to $v \mathrm{C}-\mathrm{H}$ aliphatic corresponding to n-hexane and $\mathrm{CHO}$ (of dialdehydes) groups. A strong band was indicated within $1694-1661 \mathrm{~cm}^{-1}$ due to $v \mathrm{C}=\mathrm{O}$ of aldehyde or ketone group. The band within $1595-1590 \mathrm{~cm}^{-1}$ was assigned for $v \mathrm{C}=\mathrm{C}$ aromatic rings and the band within $1233-1257 \mathrm{~cm}^{-1}$ for $v \mathrm{C}-\mathrm{O}-\mathrm{C}$ of etheric bond (supplementary Fig. S3-S5), similar assignments have been reported in the literature for dicarbonyl monomers. ${ }^{36,37}$

The polymers P $m$ HOBND and PoHONPD showed weak band at 1694 and $1683 \mathrm{~cm}^{-1}$ respectively for $v \mathrm{C}=\mathrm{O}$ contributed from end on group, this band was present as a strong band in their corresponding monomers which showed that carbonyl group was converted into imine group. All the three polymers (P $m$ HOBND, PoHONPD and PoHOAND) showed strong to medium intensity band within $1594-1620 \mathrm{~cm}^{-1}$ for $v \mathrm{C}=\mathrm{N}$ and the band within $1592-1518 \mathrm{~cm}^{-1}$ due to aromatic rings of the polymers. Two bands were observed within $1237-1248 \mathrm{~cm}^{-1}$ and $1024-1005 \mathrm{~cm}^{-1}$ due to $v \mathrm{C}-\mathrm{O}-\mathrm{C}$ asymmetric and symmetric vibrations and number of bands within 973$681 \mathrm{~cm}^{-1}$ were for $\mathrm{C}-\mathrm{H}$ in plane and out of plane vibrations of aromatic rings (Figure 4) (supplementary Fig. S6 and S7). Similar assignments indicated for related polymines. $^{36,38}$

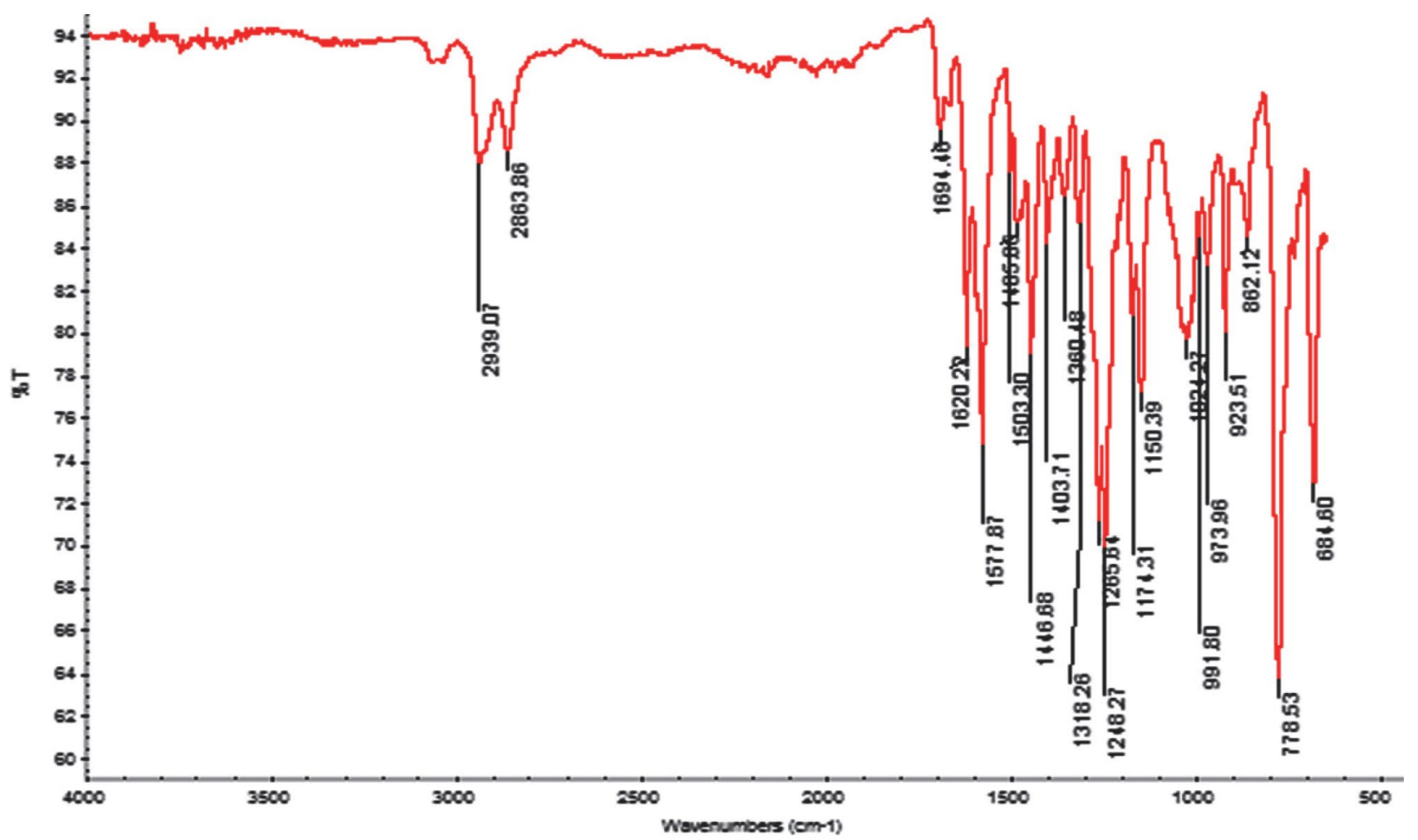

Figure 4. FT-IR spectrum of polymer PmHOBND 


\section{5. ${ }^{1}$ HNMR Spectroscopy of Monomers and Polymers}

The ${ }^{1} \mathrm{HNMR}$ spectra of all the synthesized compounds (monomers and polymers) were recorded in DMSO- $d_{6}$ solvent. The dialdehyde monomers $m$-HOB and $o$-HON indicated $\mathrm{CHO}$ group signal at $\delta$ ppm 9.959 and 10.794 respectively, all the three monomers $(m-\mathrm{HOB}$, $o$-HON and $o$-HOA showed signals within the range of $\delta$ ppm 6.989-8.257 due to protons of the aromatic rings (benzene or naphthalene), one triplet within $\delta \mathrm{ppm} 4.050-$ 4.324 due to etheric group $\left(\mathrm{O}-\mathrm{CH}_{2}\right)$ protons and $\mathrm{CH}_{2}$ aliphatic protons signals within $\delta \mathrm{ppm}$ range of 1.361-1.871 due to $\mathrm{n}$-hexane while diketone $o$-HOA also showed signal at $\delta \mathrm{ppm} 2.534$ due to $\mathrm{CH}_{3}$ protons of acetophenone group (supplementary Fig. S8-S10). The polymers P $m$ HOBND and $\mathrm{PoHONPD}$ showed singlet at $\delta$ ppm 7.942 for azomethine group proton $(\mathrm{CH}=\mathrm{N})$ while the polymer $\mathrm{PoHO}$ AND did not showed any proton signal at this position because it contains imine bond $(\mathrm{C}=\mathrm{N})$ instead of azomethine group. The polymer $\mathrm{PoHOAND}$ showed $\mathrm{CH}$ aromatic proton signals within $\delta$ ppm range of 6.594-7.509 while aromatic $\mathrm{CH}$ signals were missing in $\mathrm{P} m \mathrm{HOBND}$ and $\mathrm{Po}$ HONPD because of their lower solubility in DMSO- $d_{6}$, the polymers $\mathrm{P} m \mathrm{HOBND}$ and $\mathrm{P} o \mathrm{HOAND}$ indicated triplet at $\delta$ ppm 4.052 and 4.078 due to $\mathrm{OCH}_{2}$ group, all the three polymers showed signals within the range of $\delta \mathrm{ppm} 1.417-$ 2.880 due to $\mathrm{CH}_{2}$ group protons of $\mathrm{n}$-hexnane and $\mathrm{PoHO}$ -
AND showed singlet at $\delta$ ppm 2.275 due to $\mathrm{CH}_{3}$ group protons (Figure 5). Similar ${ }^{1} \mathrm{HNMR}$ assignment have been reported for related monomers and polymers. ${ }^{38,39}$

\section{6. UV-Vis Spectroscopy of Monomers and Polymers}

UV-visible spectra of monomers and polymers were recorded using DMSO solvent and the results including molar absorptivity $\left(\mathrm{L} \cdot \mathrm{mole}{ }^{-1} \cdot \mathrm{cm}^{-1}\right)$ of monomers and $1 \%$ absorptivity of polymers (because molecular weight of polymers was unknown) are provided in Table 2. The meta oriented monomer $m$-HOB showed only one band at $314 \mathrm{~nm}$ for $\pi-\pi^{*}$ transition within aromatic ring while the ortho oriented monomers $o$-HON and $o$-HOA showed two bands each, the first bands at $320 \mathrm{~nm}$ and $306 \mathrm{~nm}$ respectively were attributed to $\pi-\pi^{*}$ transition within aromatic ring and second at $340 \mathrm{~nm}$ and $444 \mathrm{~nm}$ respectively was for $\pi-\pi^{*}$ within conjugated aromatic ring and carbon$\mathrm{yl}(\mathrm{C}=\mathrm{O})$ group. The appearance of second peak in ortho oriented monomers may be due to greater influence of lone pairs of oxygen on conjugation as compared to meta oriented monomer (supplementary Fig. S11-S13). All the three polymers showed two bands, the first band appeared due to $\pi-\pi^{*}$ transition within aromatic ring and the second band was due to $\pi-\pi^{*}$ transition involving aromatic ring (phenyl or naphthyl) and conjugated azomethine



Figure 5. ${ }^{1} \mathrm{HNMR}$ spectrum of polymer PoHOAND 
Table 2. Results of spectrophotometric studies of monomers and polymers in DMSO Solvent

\begin{tabular}{|c|c|c|c|}
\hline S. No & Compound & $\lambda \mathrm{nm}(\varepsilon 1 \%)$ & Possible transition \\
\hline 1 & $m \mathrm{HOB}$ & $314(6976)$ & $\pi-\pi^{\star}$ transition within benzaldehyde ring system \\
\hline 2 & PmHOBND & $\begin{array}{c}287(145) \\
321(236.5)\end{array}$ & $\begin{array}{l}\qquad \pi-\pi^{\star} \text { transition within aromatic ring system } \\
\pi-\pi^{*} \text { transition involving naphthyl ring and conjugated } C=C-N=C \pi \text {-electron system }\end{array}$ \\
\hline 3 & $o \mathrm{HON}$ & $\begin{array}{l}320(3043) \\
340(2199)\end{array}$ & $\begin{array}{c}\pi-\pi^{*} \text { transition within naphthaldehyde ring system } \\
\pi-\pi^{*} \text { transition involving naphthyl ring with conjugated } \mathrm{O}=\mathrm{C}-\mathrm{C}=\mathrm{C}-\mathrm{O} \pi \text {-electron system } \\
\text { and lone pair of etheric oxygen. }\end{array}$ \\
\hline 4 & PoHONPD & $\begin{array}{l}265(1120) \\
318(940)\end{array}$ & $\begin{array}{c}\pi-\pi^{*} \text { transition within aromatic ring system } \\
\pi-\pi^{*} \text { transition involving phenyl ring and conjugated } C=C-N=C \pi \text {-electron system }\end{array}$ \\
\hline 5 & $o \mathrm{HOA}$ & $\begin{array}{l}306(7076) \\
444(233.7)\end{array}$ & $\begin{array}{c}\pi-\pi^{*} \text { transition within acetophenone ring system } \\
\pi-\pi^{*} \text { transition involving naphthyl ring with conjugated } \mathrm{O}=\mathrm{C}-\mathrm{C}=\mathrm{C}-\mathrm{O} \pi \text {-electron system } \\
\text { and lone pair of etheric oxygen }\end{array}$ \\
\hline 6 & PoHOAND & $\begin{array}{l}307(1580) \\
477(500)\end{array}$ & $\begin{array}{l}\qquad \pi-\pi^{*} \text { transition within aromatic ring system } \\
\pi-\pi^{*} \text { transition involving phenyl ring and conjugated } C=C-N=C \pi \text {-electron system }\end{array}$ \\
\hline
\end{tabular}

( $\mathrm{C}=\mathrm{C}-\mathrm{N}=\mathrm{C}$ ) group (Figure 6) (supplementary Fig. S14-S15). Similar UV-Vis assignment for related monomers and polymers were reported. ${ }^{40,41}$

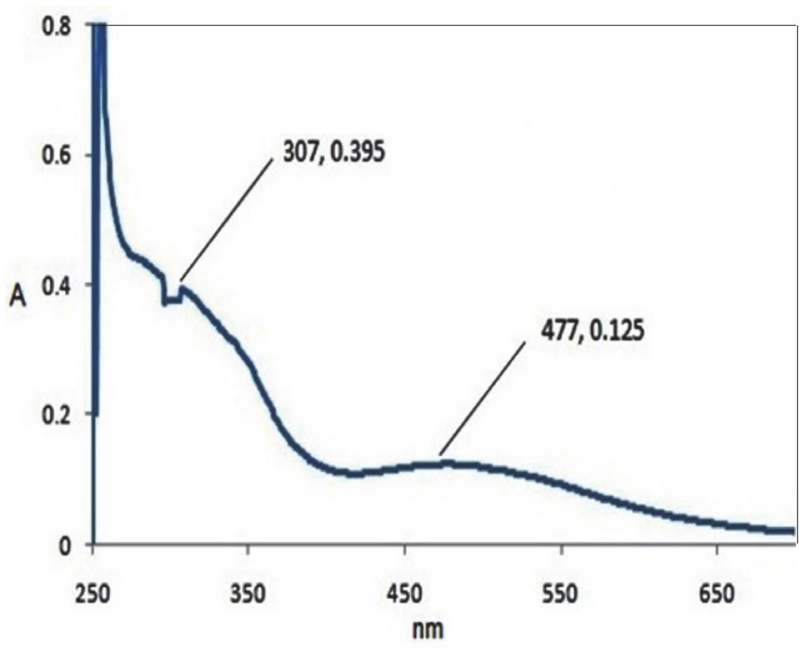

Figure 6. UV/Vis Spectrum of polymer (PoHOAND)

\section{7. Fluorescence Spectroscopy of Monomers and Polymers}

All the synthesized monomers and polymers indicated fluorescence emission due to the presence of conjugated chromophoric groups in their structure (supplementary Fig. S16-S20). The fluorescence quantum yields of the synthesized compounds were calculated at different excitation wavelengths through reported comparative method. ${ }^{42}$ Quinine sulphate was dissolved in $0.1 \mathrm{M} \mathrm{H}_{2} \mathrm{SO}_{4}$ and used as standard for all the measurements while the solutions of monomers and polymers were prepared in DMSO. The excitation and emission spectra of both the compound (monomers and polymers) and standard (qui- nine sulphate) were recorded at solutions concentration $0.025 \mathrm{mg} / \mathrm{ml}$ because maximum emission intensities of the synthesized compounds were observed at this concentration. The excitation and emission slit width was adjusted at $5 \mathrm{~nm}$ for both the compound (monomers and polymers) and standard (quinine sulphate). The quantum yields of monomers and polymers were calculated using the following equation 3

$$
Q_{M X}=Q_{Y S}\left[\frac{A_{x}}{A_{S}}\right] \times\left[\frac{f_{s}}{f_{x}}\right] \times\left[\frac{n_{x}}{n_{S}}\right]
$$

Where $\mathrm{Q}_{\mathrm{MX}}$ is the quantum yield of compound whose quantum yield want to be calculated, $\mathrm{Q}_{\mathrm{YS}}$ is the quantum yield of quinine sulphate standard (0.54), $\mathrm{A}_{\mathrm{x}}$ is the area under the emission peak of the compound whose quantum yield want to be calculated, $A_{s}$ is area under the emission peak of quinine sulphate standard (190059), $f_{s}$ $\left(1-10^{-\mathrm{D}}\right.$, D: absorbance value $(0.20)$ of the quinine sulphate standard measured in UV-Vis at excitation wavelength), $\mathrm{f}_{\mathrm{x}}\left(1-10^{-\mathrm{D}}, \mathrm{D}\right.$ : absorbance value of the compound measured in UV-Vis at excitation wavelength), $\mathrm{n}_{\mathrm{x}}$ is the refractive index of DMSO (1.479), $\mathrm{n}_{\mathrm{x}}$ is the refractive index of $0.1 \mathrm{M} \mathrm{H}_{2} \mathrm{SO}_{4}$ (1.33). All the monomers and polymers showed different color emissions at different excitation wavelengths, the results of spectrofluorometric measurements of all the monomers and polymers with their calculated quantum yields are summarized in Table 3. The monomers $m \mathrm{HOB}$ and $o \mathrm{HON}$ showed red and violet light emissions while the monomer oHOA showed violet, orange and red light emissions, the calculated quantum yields of monomers were obtained within the range of 0.04 to $3.35 \%$. The polymer $\mathrm{P} m$ HOBND showed red and violet light emissions, PoHONPD showed violet light emission and PoHOAND indicated violet, bluegreen and orange light emission, the calculated quantum 
Table 3. Spectrofluorometric determination of monomers and polymers in DMSO solvent

\begin{tabular}{|c|c|c|c|c|c|c|}
\hline S. No & Compound & $\begin{array}{c}\text { Excitation } \\
\text { wavelength }(\mathrm{nm})\end{array}$ & $\begin{array}{c}\text { Emission } \\
\text { wavelength }(\mathrm{nm})\end{array}$ & $\begin{array}{l}\text { Emission } \\
\text { color }\end{array}$ & $\begin{array}{c}\text { Relative intensity } \\
\text { of emission }\end{array}$ & $\% Q_{M X}$ \\
\hline \multirow{3}{*}{1} & \multirow{3}{*}{$m \mathrm{HOB}$} & \multirow{3}{*}{314} & 348 & - & 274 & 3.1 \\
\hline & & & 631 & red & 16.9 & 0.04 \\
\hline & & & 691 & red & 24.3 & 0.33 \\
\hline \multirow{3}{*}{2} & \multirow{3}{*}{$\mathrm{P} m \mathrm{HOBND}$} & \multirow{3}{*}{321} & 398 & violet & 1016 & 24.3 \\
\hline & & & 645 & red & 22.2 & 0.04 \\
\hline & & & 742 & red & 400 & 6.27 \\
\hline \multirow{5}{*}{3} & \multirow{5}{*}{$o \mathrm{HON}$} & \multirow{3}{*}{320} & 357 & - & 79.4 & 2.50 \\
\hline & & & 642 & red & 39.6 & 0.20 \\
\hline & & & 706 & red & 5.2 & 0.15 \\
\hline & & \multirow{2}{*}{340} & 378 & violet & 89.9 & 0.56 \\
\hline & & & 681 & red & 36.11 & 0.36 \\
\hline \multirow{2}{*}{4} & \multirow{2}{*}{ PoHONPD } & 265 & 356 & - & 403 & 7.38 \\
\hline & & 318 & 374 & violet & 345.4 & 4.92 \\
\hline \multirow{3}{*}{5} & \multirow{3}{*}{$o \mathrm{HOA}$} & \multirow{3}{*}{306} & 380 & violet & 217.5 & 3.35 \\
\hline & & & 614 & orange & 21.36 & 0.04 \\
\hline & & & 688 & red & 14.6 & 0.22 \\
\hline \multirow{3}{*}{6} & \multirow{3}{*}{ PoHOAND } & \multirow{2}{*}{307} & 391 & violet & 442 & 4.81 \\
\hline & & & 616 & orange & 47.3 & 0.06 \\
\hline & & 477 & 513 & blue-green & 50.2 & 0.2 \\
\hline
\end{tabular}

$\% \mathrm{Q}_{\mathrm{MX}}$ (calculated \% quantum yield of monomers and polymers)
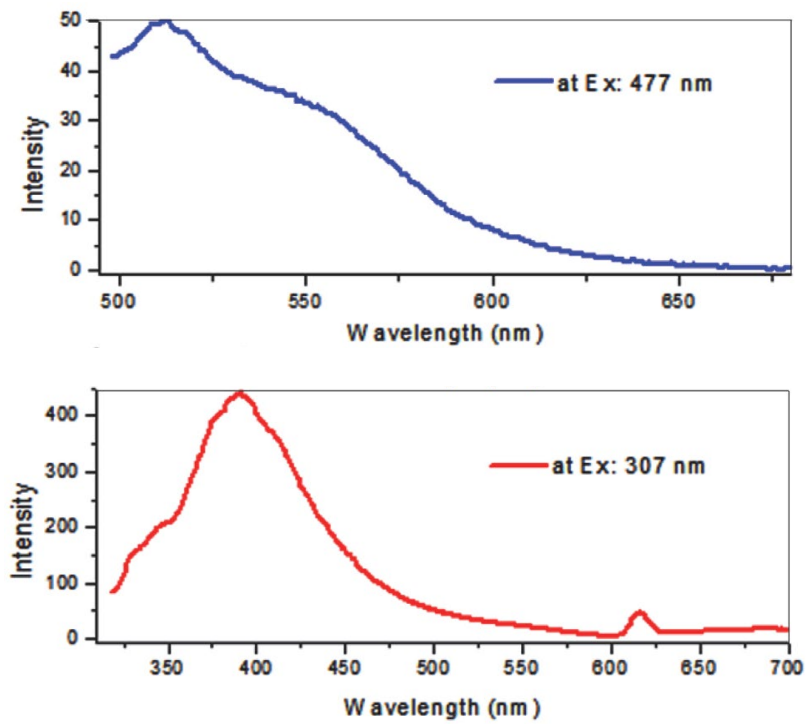

Figure 7. Fluorescence emission spectra of polymer PoHOAND at different excitation wavelengths

yields of polymers were obtained within the range of 0.04 to $24.3 \%$. The fluorescence quantum yields of all the polymers were higher than their corresponding monomers while the polymer PmHOBND indicated highest quantum efficiency among all the synthesized compounds which is $24.3 \%$ for violet light emission ( $398 \mathrm{~nm}$ ) at excitation $321 \mathrm{~nm}$.

\section{8. Scanning Electron Microscopy of Monomers and Polymers}

The SEM images of monomers and polymers were recorded at micron marker scale length range of $500 \mu \mathrm{m}$ to $1 \mu \mathrm{m}$ at different magnifications. The dialdehyde $m$-HOB showed crystalline morphology and looked like iron blocks while its corresponding polymer $\mathrm{P} m \mathrm{HOBND}$ had sponge like morphology. The monomer $o$-HON had clay rock like morphology and showed non-homogeneous surface, while its corresponding polymer PoHONPD showed smooth and porous surface (supplementary Fig. S21 and S22). The surface morphology of diketone monomer $o$-HOA was fibrous and looked like cotton wool while morphology of its corresponding polymer PoHOAND looked like cheese pieces with clearly visible pores of different sizes (Figure 8). The surface morphology of all the three polymers was different from their corresponding monomers which support their formation.

\section{9. Powdered X-ray Diffraction (XRD) of Polymers}

The X-ray diffraction patterns of the polymers were acquired over $2 \theta$ range of $5^{\circ}-80^{\circ}$ (Figure 9). The meta-oriented polymer $\mathrm{P} m \mathrm{HOBND}$ showed intense peaks within $2 \theta=5^{\circ}-30^{\circ}$ which indicates its semicrystalline nature which may be attributed to the presence of polar $\mathrm{CH}=\mathrm{N}$ 


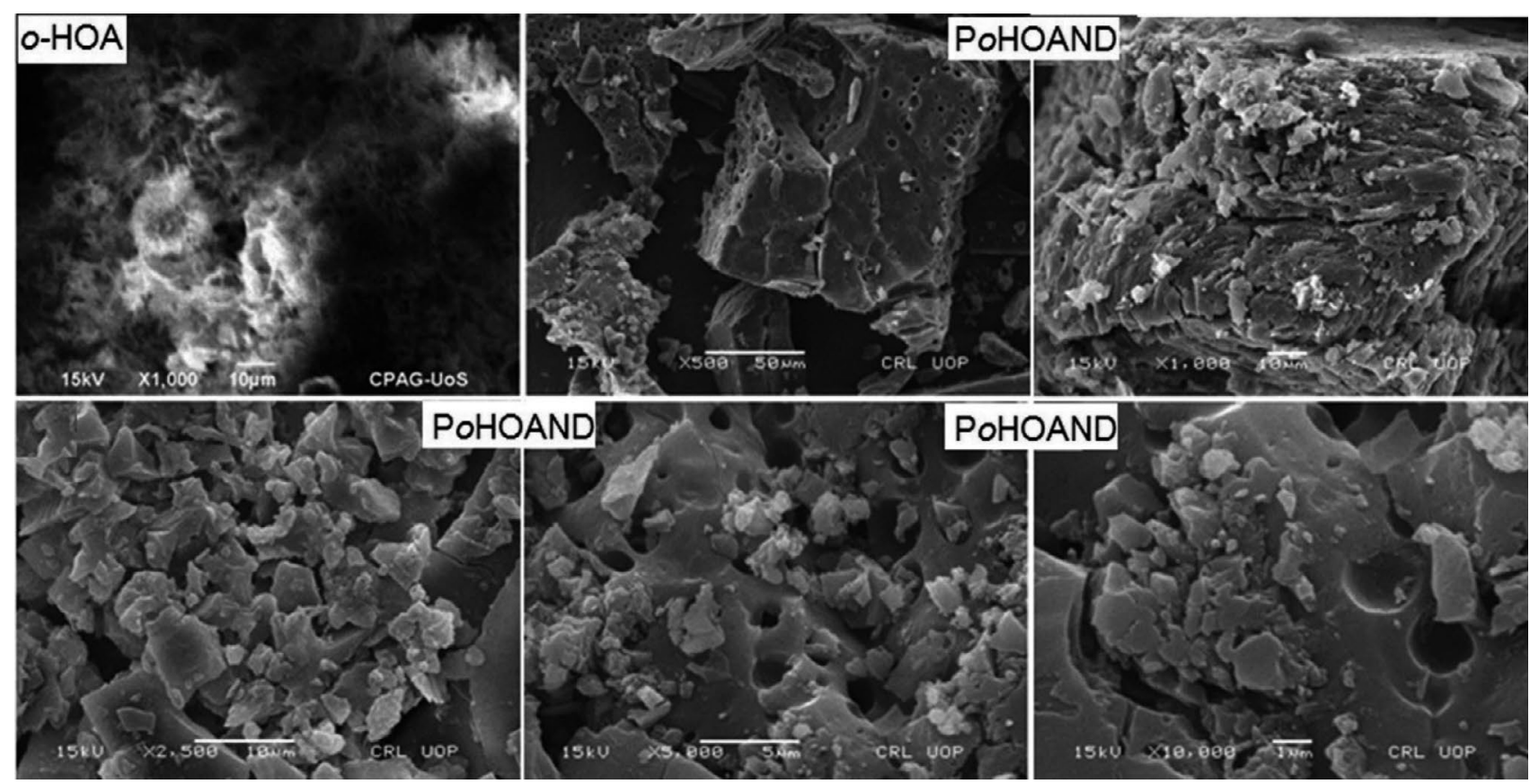

Figure 8. SEM images of monomer $o$-HOA and its derived polymer PoHOAND at different micron-marker scale lengths $(50 \mu \mathrm{m}$ to $1 \mu \mathrm{m})$

groups and $\mathrm{C}=\mathrm{C}$ bonds of aromatic rings in its structure. ${ }^{43}$ The polymers PoHONPD and PoHOAND showed one broad diffraction hump centered at $2 \theta=20.6^{\circ}$ and $2 \theta=$ $22.5^{\circ}$ respectively, which indicated their amorphous na-

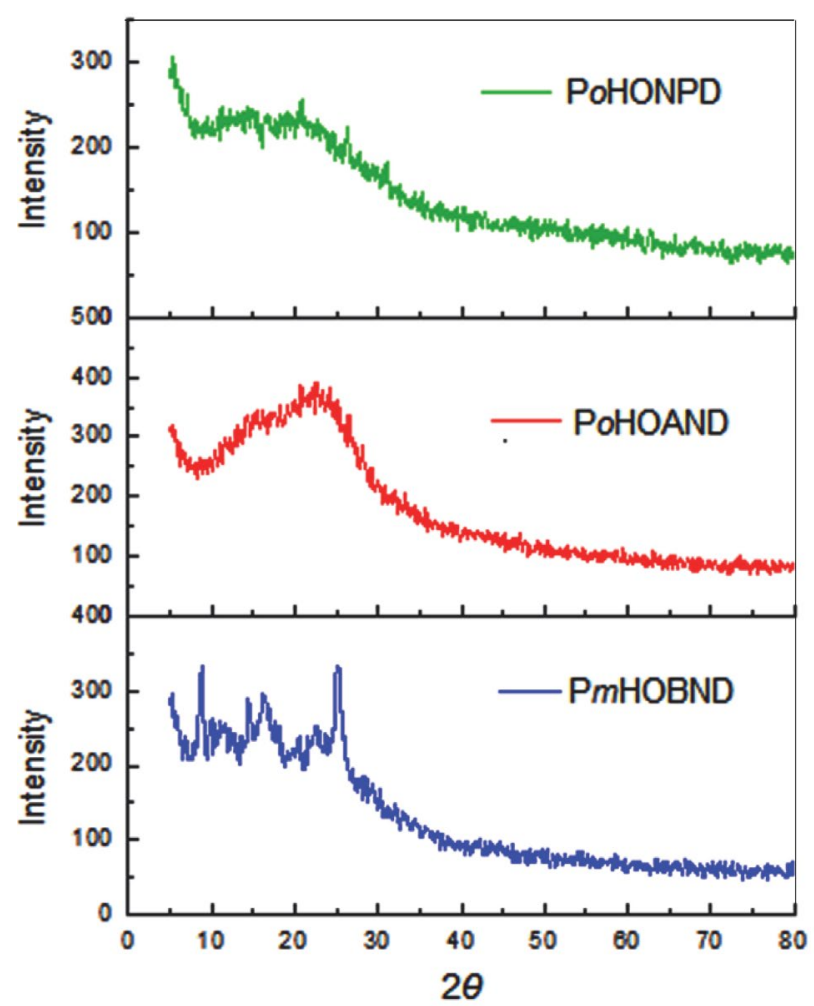

Figure 9: XRD patterns of polymers $\mathrm{P} m \mathrm{HOBND}, \mathrm{PoHOAND}$ and PoHONPD ture. ${ }^{44}$ The amorphous nature of ortho oriented polymers (PoHONPD and PoHOAND) was due to the presence of 1,2- linkages and flexible aliphatic $\left(\mathrm{CH}_{2}\right)_{6}$ groups in their structures. ${ }^{45}$

\section{10. Thermal Analysis of Monomers and Polymers}

Thermal properties of monomers and polymers were evaluated by thermogravimetric (TG) and differential thermal analysis (DTA) and the results are summarized in Table 4. Thermal stability of the compounds was estimated from the $\mathrm{T}_{\max }$ value (temperature indicating maximum rate of weight loss) in TG graph. TG of dialdehyde $m$-HOB indicated weight loss in single step of $93 \%$ within $265{ }^{\circ} \mathrm{C}-590{ }^{\circ} \mathrm{C}$ and $\mathrm{T}_{\max }$ value at $394{ }^{\circ} \mathrm{C}$, DTA showed two endotherms first at $82^{\circ} \mathrm{C}$ due to melting and second at $324{ }^{\circ} \mathrm{C}$ for vaporization/decomposition followed by four exotherms due to decomposition at 263 , 393,479 and $558^{\circ} \mathrm{C}$. TG of $o$-HON showed three steps of weight loss, $54 \%$ weight loss within $294-413{ }^{\circ} \mathrm{C}, 14 \%$ loss within $414-514{ }^{\circ} \mathrm{C}$ and $19 \%$ loss within $515-611^{\circ} \mathrm{C}$, its $\mathrm{T}_{\max }$ was observed at $354^{\circ} \mathrm{C}$, DTA indicated one endotherm at $193^{\circ} \mathrm{C}$ due to melting followed by two exotherms at $362{ }^{\circ} \mathrm{C}$ and $545{ }^{\circ} \mathrm{C}$ due to decomposition. TG of diketone monomer $o$-HOA showed three steps of weight loss, $71 \%$ loss within $209-377^{\circ} \mathrm{C}, 12 \%$ loss within $378-490^{\circ} \mathrm{C}$ and $9 \%$ loss indicated within $491-550^{\circ} \mathrm{C}$, its $\mathrm{T}_{\max }$ was observed at $342{ }^{\circ} \mathrm{C}$, DTA showed melting endotherm at 97 ${ }^{\circ} \mathrm{C}$, vaporization/decomposition exotherm at $371{ }^{\circ} \mathrm{C}$ and large decomposition exotherm at $545{ }^{\circ} \mathrm{C}$. The dialdehyde $m$-HOB indicated highest thermal stability among the 
Table 4. Thermal analysis (TG/DTA) data of monomers and polymers

\begin{tabular}{|c|c|c|c|c|c|c|}
\hline \multirow{4}{*}{ Compound } & \multicolumn{4}{|c|}{ TG } & \multirow{3}{*}{\multicolumn{2}{|c|}{ DTA }} \\
\hline & \multirow{3}{*}{\multicolumn{3}{|c|}{$\begin{array}{l}\text { Weight loss stages } \\
\text { I } \\
\text { Wt. loss } \%\left(\text { temperature range }{ }^{\circ} \mathrm{C}\right)\end{array}$}} & \multirow{3}{*}{$\begin{array}{l}\text { Maximum rate } \\
\text { of wt. loss } \\
\left(\mathrm{T}_{\max }{ }^{\circ} \mathrm{C}\right)\end{array}$} & & \\
\hline & & & & & & \\
\hline & & & & & Endo ${ }^{\circ} \mathrm{C}$ & Exo ${ }^{\circ} \mathrm{C}$ \\
\hline$m$-HOB & $93(265-590)$ & - & - & 394 & 82,324 & $263,393,479,558$ \\
\hline$o-\mathrm{HON}$ & $54(294-413)$ & $14(414-514)$ & $19(515-611)$ & 354 & 193 & 362,545 \\
\hline$o$-HOA & $71(209-377)$ & $12(378-490)$ & $9(491-550)$ & 342 & 97 & 371,545 \\
\hline PmHOBD & $8(194-415)$ & $36(416-503)$ & $50(504-651)$ & 577 & - & 456,639 \\
\hline PoHONPD & $44(324-468)$ & $6(469-557)$ & $39(558-678)$ & 396 & - & $54,365,448,624$ \\
\hline PoHOAND & $98(42-727)$ & - & - & 385 & - & 676 \\
\hline
\end{tabular}

monomers (supplementary Fig. S23-S25). TG of polymer P $m$ HOBND indicated weight loss in three steps $8 \%$ loss was observed within $194-415{ }^{\circ} \mathrm{C}, 36 \%$ weight loss within $416-503^{\circ} \mathrm{C}$ and $50 \%$ loss within $504-651^{\circ} \mathrm{C}$ with $\mathrm{T}_{\max }$ at $577^{\circ} \mathrm{C}$. DTA showed two exothermic curves, vaporization/decomposition exotherm at $456{ }^{\circ} \mathrm{C}$ and decomposition exotherm at $639^{\circ} \mathrm{C}$ (Figure 10a). TG of $\mathrm{Po}$ HONPD showed three steps of weight loss, $44 \%$ weight loss was observed within $324-468^{\circ} \mathrm{C}, 6 \%$ weight loss within $469-557^{\circ} \mathrm{C}$ and $39 \%$ weight loss within $558-678{ }^{\circ} \mathrm{C}$, $\mathrm{T}_{\max }$ showed at $396^{\circ} \mathrm{C}$, DTA showed two volatilization/ decomposition exotherms at $365^{\circ} \mathrm{C}$ and $448^{\circ} \mathrm{C}$ and large decomposition exotherm at $624^{\circ} \mathrm{C}$ (Figure 10b). TG of PoHOAND indicated $98 \%$ weight loss within $42-727^{\circ} \mathrm{C}$ in one step with $\mathrm{T}_{\max }$ at $385^{\circ} \mathrm{C}$, DTA showed one exotherm at $676^{\circ} \mathrm{C}$ due to decomposition (Figure 10c). Thermal stability of the polymers was higher than their corresponding monomers and the polymer PmHOBND showed higher $\mathrm{T}_{\max }$ value $\left(577^{\circ} \mathrm{C}\right)$ among all the synthesized compounds.

\section{11. Biological Activities of Polymers}

The antimicrobial activities of the polymers were examined against different species of bacteria and fungi but the polymers showed non-significant antimicrobial activities. The polymer P $m$ HOBND showed $10 \%$ antibacterial activity against Staphylococcus aureus and Bacillus subtilis while only $2 \%$ inhibition against Salmonella typhi. PoHOBND showed 11\% inhibition against Staphylococcus aureus, $8 \%$ inhibition against Bacillus subtilis and 7.4\% inhibition against Salmonella typhi. PoHOAND indicated no inhibition against Staphylococcus aureus, only 1\% inhibition against Bacillus subtilis and $15.4 \%$ inhibition against Salmonella typhi. All the three polymers not showed any activity against Escherichia coli and Pseudomonas aeruginosa. The polymers $\mathrm{P} m \mathrm{HOBND}$ and PoHOBND showed $12.5 \%$ antifungal activity against Candida albicans while PoHOAND showed $10 \%$ activity against the same strain. All the three polymers did not show any activity against Canadida glabrata, Aspergillus niger, Fusarium lini, Trichphyton rubrum and Microsporum canis.


Figure 10. TG/DTA graphs of polymers (a) PmHOBND (b) PoHONPD (c) PoHOAND 

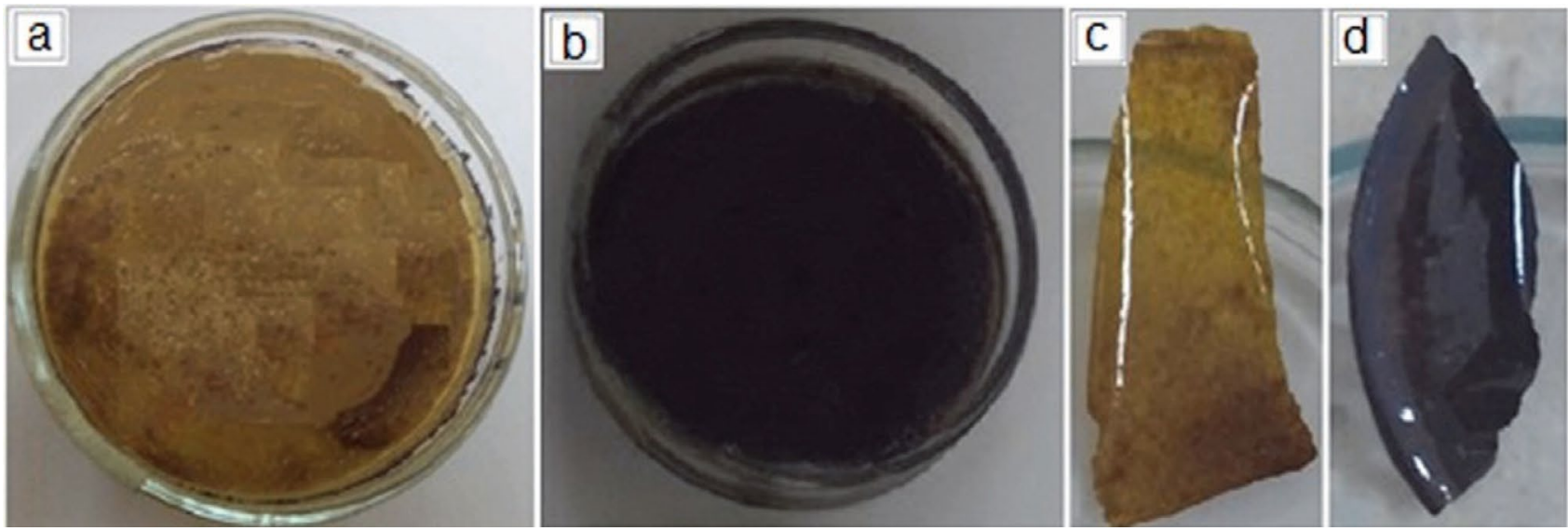

Figure 11.Images of dried homogenized polymer-PVC blends (50-50\%) w/w and their resulting thin films (a) PoHONPD-PVC blend (b) PoHOAND-PVC blend (c) thin film of PoHONPD-PVC and (d) thin film of PoHOAND-PVC.

\section{11. Thin Films of Polymer-PVC Blends}

The polymers $\mathrm{P} m \mathrm{HOBND}$, PoHONPD and $\mathrm{PoHO}-$ AND were tested for their thin film forming ability, the synthesized polymers could not form thin films alone therefore polymer-PVC blends in different $\mathrm{w} / \mathrm{w} \%$ ratios $(10: 90,20: 80,30: 70,40: 60$ and 50:50) were prepared, among them only 50:50 w/w\% blends of ortho-oriented polymers PoHONPD and PoHOAND were transformed into thin layers having shiny finishing (Figure 11).

\section{Conclusion}

Three new aliphatic-aromatic polyimines containing naphthyl rings in their main chain were prepared by the polycondensation reaction of newly synthesized dialdehydes and diketone monomers with diamines. The solubility of the polymers were improved significantly due to solubility enhancing arrangements made in their structures which include their aliphatic-aromatic nature, introduction of ether linkages between the aliphatic and aromatic groups and non-linear orientation (ortho and meta) of the groups attached with the aromatic ring. In addition to these structural modifications the polymer PoHOAND contain methyl side group attached at ortho position of the aromatic ring and this polymer indicates highest solubility among the synthesized polymer, it was soluble in all the organic solvent tested which include acetone, chloroform, THF, DMF and DMSO. All the synthesized compounds (monomers and polymers) were fluorescent, the polymer P $m$ HOBND showed violet and red light emission, PoHONPD showed violet light emission while PoHOAND showed multi-color emissions which include violet, blue-green and orange. The highest quantum yield (24.3\%) was indicated by the meta-oriented polymer $\mathrm{P} m \mathrm{HOBND}$ for violet light emission $(398 \mathrm{~nm})$ at excitation $321 \mathrm{~nm}$. The polymers were thermally stable up to $400^{\circ} \mathrm{C}$, therefore they can be applied as fluo- rescent and heat-resistant materials. The $50: 50 \mathrm{w} / \mathrm{w} \%$ polymer-PVC blends of PoHONPD and PoHOAND were transformed into thin films with shiny finishing.

\section{References}

1. K. Suematsu, K. Nakamura, and J. Takeda, Colloid Polym. Sci. 1983, 261, 493-501. DOI:10.1007/BF01419833

2. S. Banerjee and C. Saxena, J Polym Sci A Polym Chem. 1996, 34, 3565-3572.

DOI:10.1002/(SICI)1099-0518(199612)34:17<3565::AIDPOLA11>3.0.CO;2-C

3. P. Kumar Gutch, S. Banerjee, D. Gupta, and D. Jaiswal, J Polym Sci A Polym Chem. 2001, 39, 383-388.

DOI:10.1002/1099-0518(20010201)39:3<383::AID-POLA1005>3.0.CO;2-3

4. M. A. Hussein, M. A. Abdel-Rahman, A. M. Asiri, K. A. Alamry, and K. I. Aly, Des. Monomers Polym. 2012, 15, 431-463. DOI:10.1080/1385772X.2012.688325

5. N. Khalid, A. Bibi, K. Akhtar, K. Mustafa, M. Khan, and N. Saeed, Polym Plast Technol Eng. 2019, 15, 419-426.

DOI:10.1080/03602559.2018.1471719

6. E. Hamciuc, M. Homocianu, C. Hamciuc, and I.-D. Carja, High Perform Polym. 2018, 30, 339-346.

DOI:10.1177/0954008317697367

7. M. Palewicz, A. Iwan, A. Sikora, J. Doskocz, W. Strek, D. Sek, and B. Mazurek, Acta Phys. Pol. A. 2012, 121, 439-444.

DOI:10.12693/APhysPolA.121.439

8. S. Dineshkumar, A. Muthusamy, P. Chitra, and S. Anand, J ADHES SCI TECHNOL. 2015, 29, 2605-2621.

DOI:10.1080/01694243.2015.1079455

9. İ. Kaya, A. Avcı, F. Kolcu, and S. Çulhaoğlu, Des. Monomers Polym. 2014, 17, 481-490.

DOI:10.1080/15685551.2013.867581

10. H. Niu, Y. Huang, X. Bai, X. Li, and G. Zhang, Mater Chem Phys. 2004, 86, 33-37.

DOI:10.1016/j.matchemphys.2004.01.023 
11. P. W. Wojtkowski, Macromolecules. 1987, 20, 740-748. DOI:10.1021/ma00170a0077

12. T. Borukaev, A. K. Shaov, A. Kharaev, R. C. Bazheva, L. Pashtova, A. K. Malamatov, and V. Shogenov, Fibre Chemistry. 2018, 49, 425-427. DOI:10.1007/s10692-018-9913-3

13. M. Palewicz, A. Iwan, J. Doskocz, W. Strek, D. Sek, B. Kaczmarczyk, and B. Mazurek, Polym. Bull. 2011, 66, 65-76. DOI:10.1007/s00289-010-0308-8

14. B. Jarząbek, B. Kaczmarczyk, J. Jurusik, M. Siwy, and J. Weszka, J. Non-Cryst. Solids. 2013, 375, 13-18.

DOI:10.1016/j.jnoncrysol.2013.05.013

15. M. Rusu, A. Airinei, G. G. Rusu, L. Marin, V. Cozan, P. RÂmbu, I. Caplanus, and G. I. Rusu, J MACROMOL SCI B. 2011, 50, 1285-1297. DOI:10.1080/00222348.2010.507444

16. M-F. Zaltariov, M. Cazacu, A. Vlad, L. Sacarescu, and S. Shova, High Perform. Polym. 2015, 27, 607-615. DOI: $10.1177 / 0954008315584176$

17. N. Nishat, S. Parveen, S. Dhyani, and Asma, J. Coord. Chem. 2009, 62, 1091-1099. DOI:10.1080/00958970802416020

18. N. Nishat, S. A. Khan, S. Parveen, and R. Rasool, J. Coord. Chem. 2010, 63, 3944-3955.

DOI:10.1080/00958972.2010.526207

19. A. Iwan, B. Boharewicz, I. Tazbir, M. Malinowski, M. Filapek, T. Kłąb, B. Luszczynska, I. Glowacki, K. P. Korona, and M. Kaminska, SOL ENERGY. 2015, 117, 246-259.

DOI:10.1016/j.solener.2015.03.051

20. K. Gawlinska, A. Iwan, Z. Starowicz, G. Kulesza-Matlak, K. Stan-Glowinska, M. Janusz, M. Lipinski, B. Boharewicz, I. Tazbir, and A. Sikora, OPTO-ELECTRON REV. 2017, 25, 274-284. DOI:10.1016/j.opelre.2017.07.004 4

21. C. Mallet, M. Le Borgne, M. Starck, and W. Skene, Polym. Chem. 2013, 4, 250-254. DOI:10.1039/C2PY20703F

22. M. Kamaci and İ. Kaya, J FLUORESC. 2015, 25, 1339-1349. DOI:10.1007/s10895-015-1624-z

23. A. Iwan and D. Sek, Prog. Polym. Sci. 2008, 33, 289-345. DOI:10.1016/j.progpolymsci.2007.09.005

24. N. Nishat, R. Rasool, S. Parveen, and S. A. Khan, J. Appl. Polym. Sci. 2011, 122, 2756-2764. DOI:10.1002/app.34100

25. A. Vlad, M. Cazacu, G. Munteanu, A. Airinei, and P. Budrugeac, Eur. Polym. J. 2008, 44, 2668-2677. DOI:10.1016/j.eurpolymj.2008.05.014

26. L. Ravi Kumar, V. Sengodan, M. Balaji Prasad, K. Gopalakrishnan, and K. Sethupathi, Int J Polym Mater. 2007, 56, 197206. DOI: $10.1080 / 00914030600773628$

27. J. Runt and J. Huang, in: S. Z. D. Cheng (Ed.): Chapter 8 - Polymer blends and copolymer, Applications to polymers and plastics, Handbook of Thermal Analysis and Calorimetry. vol. 3, Elsevier Science B.V., 2002, pp. 273-294.

DOI:10.1016/S1573-4374(02)80011-5
28. Z. Youming, D. Xinrong, W. Liangcheng, and W. Taibao, J Incl Phenom Macrocycl Chem. 2008, 60, 313-319.

DOI:10.1007/s10847-007-9379-z

29. D. Nepal, S. Samal, and K. E. Geckeler, Macromolecules. 2003, 36, pp. 3800-3802. DOI:10.1021/ma0258410

30. S. B. Park, H. Kim, W. C. Zin, and J. C. Jung, Macromolecules. 1993, 26, 1627-1632. DOI:10.1021/ma00059a021

31. S. Mondal, and N. Das. RSC Advances. 2014, 4, 61383-61393. DOI:10.1039/C4RA10476E

32. R. K. Pettit, C. A. Weber, M. J. Kean, H. Hoffmann, G. R. Pettit, R. Tan, K. S. Franks, and M. L. Horton, ANTIMICROB AGENTS CH. 2005, 49, pp. 2612-2617. DOI:10.1128/AAC.49.7.2612-2617.2005

33. O. Catanescu, M. Grigoras, G. Colotin, A. Dobreanu, N. Hurduc, and C. I. Simionescu, Eur. Polym. J. 2001, 37, 2213-2216. DOI:10.1016/S0014-3057(01)00119-7

34. F. Qureshi, M. Y. Khuhawar, T. M. Jahangir, and A. H. Channar, Acta Chim Slov. 2016, 63, 113-120.

DOI:10.17344/acsi.2015.1994

35. F. Qureshi, M. Y. Khuhawar, and T. M. Jahangir, Acta Chim Slov. 2018, 65, 718-729. DOI:10.17344/acsi.2018.4419

36. S. Çulhaoğlu and İ. Kaya, 폴리머. 2015, 39, pp. 225-234. DOI:10.7317/pk.2015.39.2.225

37. S. Ankushrao, Y. Patil, V. Ubale, N. Maldar, and A. Ghanwat, J MACROMOL SCI A. 2017, 54, 411-417. DOI:10.1080/10601325.2017.1313155

38. D. Sek, B. Jarzabek, E. Grabiec, B. Kaczmarczyk, H. Janeczek, A. Sikora, A. Hreniak, M. Palewicz, M. Lapkowski, and K. Karon, Synth. Met. 2010, 160, 2065-2076. DOI:10.1016/j.synthmet.2010.07.026

39. İ. Kaya, A. Avc1, and K. Temizkan, Macromol res. 2017, 25, 45-53. DOI:10.1007/s13233-017-5002-3

40. P. Dutta, P. Jain, P. Sen, R. Trivedi, P. Sen, and J. Dutta, Eur. Polym. J. 2003, 39, 1007-1011.

DOI:10.1016/S0014-3057(02)00328-2

41. A. Hafeez, Z. Akhter, J. F. Gallagher, and H. M. Siddiqui, DES MONOMERS POLYM. 2017, 20, 74-88. DOI:10.1080/15685551.2016.1231042

42. İ. Kaya B. Ayten, and D. Şenol, Opt. Mater. 2018, 78, 421-431. DOI:10.1016/j.optmat.2018.02.057

43. N.Y. Baran, M. Karakışla, H.Ö. Demir, and M. Saçak, J. Mol. Struct. 2016, 1123, 153-161.

DOI:10.1016/j.molstruc.2016.06.028

44. F. Deng, W. He, A. S. Luyt, and Y. Y. Jiang. Chin. Chem. Lett. 2011, 22, 109-113. DOI:10.1016/j.cclet.2010.09.019

45. S. Banerjee, C. Saxena, P. K. Gutch, and D. C. Gupta. Eur. Polym. J. 1996, 32, 661-664.

DOI:10.1016/0014-3057(95)00178-6 


\section{Povzetek}

Tri nove alifatsko-aromatske polimere $\mathrm{z}$ naftilnimi obroči smo pripravili s polikondenzijo dialdehidov ali diketonskih monomerov z 1,5-naftalendiaminom ali 1,4-fenilendiaminom. Monomere smo pripravili z reakcijo aromatskega aldehida ali ketona z 1,6-dibromoheksanom. Molekulsko maso monomerov smo določili z masno spektrometrijo z elektronsko ionizacijo (EI-MS). Monomere in polimere smo karakterizirali z NMR spektroskopijo ( ${ }^{1} \mathrm{H}$ NMR), infrardečo spektroskopijo (FT-IR), UV-VIS spektroskopijo, vrstično elektronsko mikroskopijo (SEM) in termogravimetrično analizo (TG / DTA). S fluorescenčno spektroskopijo monomerov in polimerov smo določili kvantne izkoristke spojin. Pri vseh preučevanih spojinah smo zaznali fluorescenco, ki se je kazala v vijoličnih, modro-zelenih, oranžnih in rdečih emisijah. Kvantni izkoristek polimerov so bili v razponu od $0,04 \%$ do $24,3 \%$. Semikristalinično in amorfno naravo polimerov smo analizirali s pomočjo rentgenske praškovne difrakcije. Proučevali smo protimikrobne aktivnosti polimerov napram različnimi vrstam bakterij in gliv. Sposobnost tvorbe sintetiziranih polimerov s tankim filmom smo ocenili tako, da smo pripravili njihove mešanice s PVC (polivinilklorid) v različnih masnih razmerjih. 